\title{
Analisis Kebijakan Luar Negeri Qatar untuk Mengakhiri Keanggotaan dalam OPEC Tahun 2019
}

\author{
Novita Putri Rudiany dan Fauzan Ranggi Lubis \\ Universitas Pertamina
}

\begin{abstract}
ABSTRAK
Pada 1 Januari 2019 lalu, Menteri Energi Qatar, Saad Sherida Al-Kaabi, menyatakan bahwa Qatar memilih untuk mengundurkan diri dari keanggotannya di dalam OPEC. Keputusan tersebut mengakhiri 58 tahun keanggotaan Qatar dalam organisasi internasional yang bergerak di bidang minyak bumi tersebut. Pernyataan ini dilanjutkan dengan rasionalisasi terkait strategi baru yang hendak diterapkan Qatar dalam pengembangan potensi LNG (Liquefied Natural Gas). Namun, muncul asumsi bahwa alasan tersebut bukan merupakan satu-satunya yang melatarbelakangi keluarnya Qatar dari OPEC. Oleh karenanya, tulisan ini menganalisis faktor-faktor eksternal yang berpotensi untuk mempengaruhi keputusan Qatar tersebut. Pendekatan yang digunakan adalah analisis kebijakan luar negeri yang didasarkan pada kondisi di luar negara. Salah satu determinan dalam pengambilan kebijakan luar negeri tersebut adalah organisasi internasional. Oleh karenanya, faktor tersebut dititikberatkan pada OPEC sebagai organisasi internasional yang menanunginya. Argumen utama dalam tulisan ini adalah bahwa hubungan power dan sosial antar negara menjadi faktor pendorong yang melatarbelakangi sikap negara untuk memilih keluar dari organisasi.
\end{abstract}

Kata-kata Kunci: Qatar, Kebijakan Luar Negeri, OPEC, Keanggotaan

On the first day of January 2019, the Ministry of Energy and Industry of Qatar, Saa Sherida Al-Kaabi, stated that Qatar had chosen to withdraw its membership from OPEC. This decision ended the 58 years membership of Qatar in that international organization which focuses on oil. The statement was continued by the rationalization regarding Qatari new energy orientation strategy which emphasizes the development of Liquefied Natural Gas (LNG) potencies. However, there are several assumptions that showed that the LNG development is not the only reason of its withdrawal. Therefore, this article analyzes the external factors which might be the driving force of this Qatari foreign policy. This article uses the theory of foreign policy analysis approach and observes the influence of external factors. One of determinants in foreign policy analysis is the international organization. Therefore, this article elaborates the dynamics of OPEC. The main argument in this research is the fact that power and social relations between member countries becomes the driving forces which influences state's decision to withdraw from the organization.

Keywords: Qatar, Foreign Policy, OPEC, Membership 
Tepat pada awal tahun 2019 lalu, Qatar yang menjadi salah satu anggota Organization of the Petroleum Exporting Countries (OPEC) telah memutuskan untuk keluar dan mengakhiri masa keanggotaannya. Berakhirnya keanggotaan Qatar di dalam OPEC telah mendapatkan pengakuan resmi dari OPEC. Berdasarkan pernyataan Menteri Energi dan Industri Qatar yakni Saad Sherida al-Kaabi menyatakan bahwa pada tanggal 1 Januari 2019 Qatar memilih untuk mengundurkan diri dari keanggotaannya di dalam OPEC. Keberadaan Qatar sebenarnya penting dan menjadi negara yang mampu memperkuat struktur organisasi, bahkan terhitung sudah 60 tahun masa keanggotaannya dalam OPEC. Namun, kini Qatar menjadi negara Arab pertama yang memutuskan untuk keluar dari organisasi internasional OPEC. Pemerintah Qatar menyatakan bahwa penyebab mengundurkan diri dari organisasi internasional tersebut merupakan hasil rumusan kebijakan strategis Qatar terkait masa depan keamanan energi.

Pemerintah Qatar berkeinginan untuk fokus dalam mengembangkan potensi liquefied natural gas (LNG) domestik dan juga menjadikan Qatar sebagai pemasok LNG utama dunia. Keputusan penarikan diri Qatar secara tersurat dan jelas menyatakan bahwa ada keinginan dalam memfokuskan upaya perencanaan mengembangkan dan meningkatkan produksi gas alamnya dari 77 juta ton per tahun menjadi 110 juta ton di tahun-tahun mendatang (Sabga 2018). Dilansir dari situs resmi US-Qatar Business Council, ekonomi Qatar didasarkan pada produksi dan ekspor gas alam serta minyak bumi. Bahkan produk-produk yang berasal dari minyak dan gas, serta setengah dari pendapatan pemerintah juga berasal dari komoditas ini dan terdiri sekitar 90\% dari ekspor. Minyak dan gas telah menjadikan Qatar sebagai negara dengan pendapatan per kapita tertinggi kedua di dunia pada tahun 2009 yakni sebesar 76.000 Dollar Amerika (n.d. dalam usqbc.org).

Dalam jumlah produksi saat ini, kini eksplorasi dan produksi minyak bumi Qatar terhitung mampu menghasilkan sebesar 600.00o barel/ hari sekitar 2\% dari hasil produksi OPEC. Dari jumlah tersebut, Qatar mendapatkan keuntungan dari hasil ekspor melalui OPEC. Berdasarkan pendapatan ekspor minyak bersih OPEC, pada tahun 2016 Qatar mendapatkan \$25 juta dan mengalami kenaikan pada tahun 2017 yakni sebesar \$35 juta. Qatar menjadi negara dengan peringkat ke-6 dengan total pendapatan terbesar OPEC dibandingkan dengan 8 negara lainnya (IEA 2018). Berdasarkan data dari IEA (International Energy Agency), bahwa Qatar memiliki cadangan terbesar ke-9 di OPEC dan terbesar ke-13 di dunia. Minyak mentah Qatar dan kontrak produksi kondensat menempati urutan 
ke-17 di dunia, dengan sebagian besar produksi negara itu dikirim ke luar negeri untuk ekspor. Minyak telah menyumbang sekitar 40\% dari produk domestik bruto (PDB) dan sekitar 63\% dari pendapatan pemerintah.

Ditinjau dari produksi sisi LNG, Qatar memang memiliki prospek yang baik. Hasil produksi gas Qatar memang terus naik sejak eksplorasinya menjadi semakin intensif memasuki dekade 2000-an. Berawal dari nilai produksi sebesar 19.6 billion cubic meters (BCM) hingga pada tahun 2018 berada pada angka 175.5 BCM (Wang 2019). Data tersebut menunjukkan bahwa Qatar memiliki kemampuan serta kepemilikan sumber daya alam berupa LNG yang memadai untuk ditingkatkan terus menerus hingga masa mendatang. Jika dibandingkan dengan hasil produksi LNG, Qatar sebenarnya tidak memiliki masalah penurunan hasil minyak bumi. Dalam kata lain bahwasanya tanpa harus keluar dari keanggotaan OPEC, Qatar juga masih bisa mengembangkan produksi LNG-nya. Oleh karena hal itu, isu tersebut tampak sebagai justifikasi normatif dari Qatar.

Berdasarkan hal tersebut, tulisan ini mencoba menelaah adanya faktor-faktor pendorong dari luar Qatar yang melatarbelakangi pengambilankebijakanluarnegeritersebut. Tulisaninimenggunakan analisis kebijakan luar negeri dengan faktor determinan eksternal, yang lebih spesifik merujuk pada hubungan sosial antar negara dalam OPEC sebagai organisasi internasional. Argumen pertama adalah adanya distribusi power dalam OPEC pada akhirnya mempengaruhi dinamika organisasi. Sedangkan argumen kedua adalah adanya hubungan antara Qatar dengan beberapa negara anggota OPEC lainnya juga mempengaruhi posisi Qatar dalam organisasi tersebut.

\section{Organisasi Internasional sebagai Determinan Kebijakan Luar Negeri}

Salah satu konsep yang memiliki relevansi dan mampu menganalisis hubungan Qatar dan OPEC adalah konsep kebijakan luar negeri. Neack (2008) mendefinisikan bahwa kebijakan luar negeri merupakan aktivitas yang pada akhirnya mengubah perilaku negara. Dalam hal ini, Singer (1961) mengatakan bahwa pada dasarnya level analisis dalam kebijakan luar negeri ada tiga yakni sistem internasional dari level yang terluas, lalu negara, hingga pengambil kebijakan yang merupakan level terkecil. Secara singkat level analisis tersebut dapat digolongkan menjadi dua hal, yakni faktor internasional dan faktor domestik. Neack (2008) mendefinisikan level analisis sistem internasional sebagai tingkatan yang berfokus terhadap state versus state, geostrategi terhadap kekuatan regional, 
atau tindakan negara terhadap organisasi internasional. Bojang (2018) menambahkan bahwa faktor internasional yang berpotensi mempengaruhi kebijakan luar negeri adalah struktur power di level internasional, hukum internasional, organisasi internasional, aliansi dan persaingan militer.

Kebijakan luar negeri dari suatu negara beberapa kali dipengaruhi oleh posisi keanggotaannya dalam organisasi internasional. Salah satunya adalah keputusan untuk mengakhiri status keanggotaan dalam sebuah organisasi internasional. Koremenos dan Nau (2001) mengungkapkan bahwa negara biasanya memutuskan untuk keluar dari organisasi internasional untuk mengatasi dilemadilema yang ada dalam kerja sama. Hodgson (2004) menambahkan bahwa pencabutan keanggotaan dari organisasi berkaitan dengan interaksi dari negara dan struktur institusinya. Dengan demikian, Shi (2017) menegaskan bahwa pendekatan Konstruktivisme dalam menjelaskan penarikan keanggotaan suatu negara mungkin tidak dilakukan berdasarkan kalkulasi untung dan rugi, tetapi lebih kepada konsiderasi normatif dan etis.

Konsiderasi normatif dan etis ini didasarkan pada hubungan power dan sosial antar negara yang pada akhirnya mempengaruhi perubahan institusi (Shi 2017). Pertama, beberapa negara akan memiliki kecenderungan untuk secara sengaja mendesain institusi yang mampu memberikan mereka keuntungan tersendiri, sehingga institusi menjadi bias. Dalam hal ini hubungan power antar negara cenderung akan menentukan distribusi kepentingan dalam institusi dan berdampak pada stabilitas institusi tersebut apabila ada ketidakpuasan dalam distribusinya. Hal inilah yang mampu membentuk persepsi ancaman bagi negara sehingga memutuskan untuk keluar dari institusi. Kedua, hubungan sosial negara anggota menentukan kelancaran interaksi dalam sebuah institusi. Apabila terjadi perubahan hubungan sosial, suatu negara dapat memilih untuk menyatakan keberatan dalam institusi, atau bisa saja memilih keluar dari institusi internasional (Shi 2017).

Merujuk pada dua argumen tersebut, tulisan ini sebenarnya menekankan pada dua analisis utama. Pertama, bagaimana hubungan power dalam OPEC dalam mendistribusikan kepentingan. Kedua, bagaimana hubungan sosial antar negara anggota yang berdampak pada keputusan Qatar untuk keluar dari organisasi tersebut. Kedua hal ini ditelaah secara elaboratif untuk memberikan gambaran bahwa keluarnya Qatar dari OPEC tidak hanya dipengaruhi oleh keputusan domestik, tetapi juga dipengaruhi oleh faktor eksternal, yakni dinamika hubungan anggota dalam organisasi internasional. 


\section{Struktur Organisasi OPEC dan Posisi Qatar}

Negara anggota OPEC memiliki cadangan minyak yang besar dibandingkan negara non-OPEC. Menurut perkiraan saat ini sekitar 79,4\% dari cadangan minyak terbukti dunia terletak di negaranegara Anggota OPEC. Sedangkan sebagian besar cadangan minyak OPEC yang berada di Timur Tengah sekitar $64,5 \%$ dari total produksi seluruh negara anggota OPEC (BBC 2018). Hal ini kemudian menjadikan wilayah Timur Tengah sebagai wilayah terpenting bagi keberlangsungan produksi dan peranan OPEC seterusnya.

Gambar 1.1 Data Produksi Negara Anggota OPEC

\section{Opec oil production}

Million of barrels per day by country in 2017

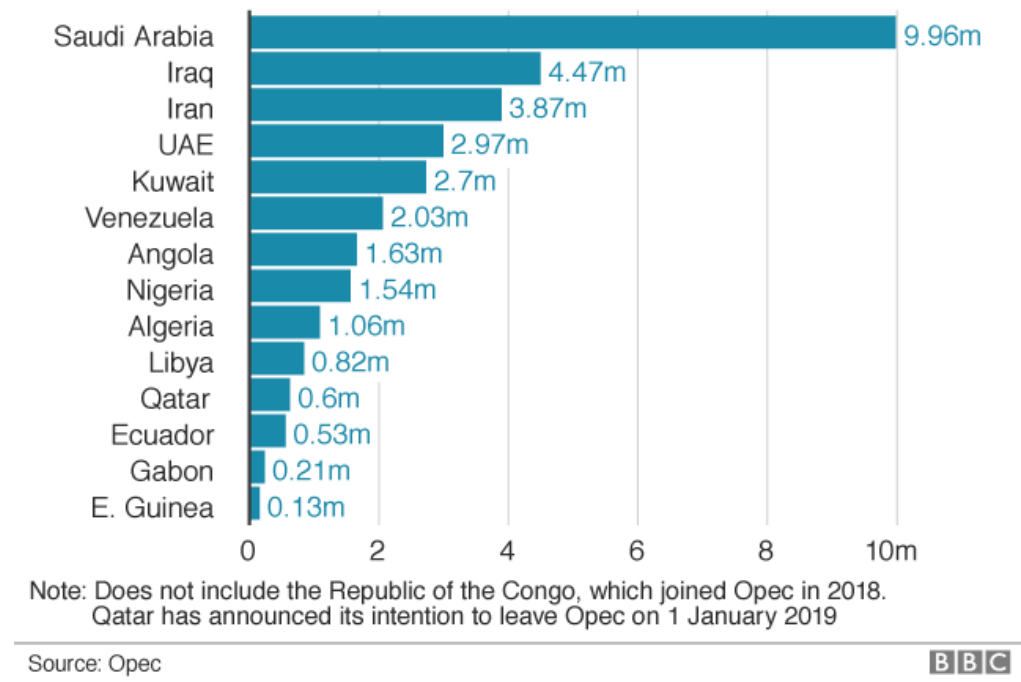

Sumber: BBC (2018)

Sekalipun menjadi kawasan penghasil minyak bumi yang dominan dalam OPEC, gambar di atas menjelaskan bahwa Qatar merupakan dengan produksi minyak yang lebih kecil dibandingkan dengan negara-negara anggota OPEC lainnya di wilayah Timur Tengah. Selain itu, Qatar sejauh ini juga belum menunjukkan pengaruh yang signifikan dalam dinamika organisasi. Banyak pendapat yang menyatakan bahwa kunci kekuatan organisasi terletak pada wilayah Timur Tengah, khususnya dari negara seperti Arab Saudi, Iraq, Iran, Uni Emirat Arab dan Kuwait, atau bisa disebut sebagai negaranegara yang mendominasi kuota produksi minyak dalam OPEC. Hal tersebut menyebabkan OPEC mendapatkan pengaruh kuat dari kelima negara Timur Tengah tersebut. 
Arab Saudi adalah salah satu negara anggota OPEC yang cenderung berperilaku sebagai pemimpin dalam OPEC. Keberadaannya dianggap sebagai de facto leader dalam organisasi. Arab Saudi menganggap OPEC sebagai bagian penting dari politik luar negerinya, sebagaimana OPEC juga membutuhkan peran penting dari Arab Saudi sebagai negara dengan produksi paling besar (AlMoneef 2011). Pengambilan keputusan dalam OPEC cenderung tersentralisasi di Arab Saudi karena memiliki kombinasi unik dari (1) cadangan minyak bumi terbesar di dalam OPEC, (2) populasi kecil yang membutuhkan lebih sedikit pendapatan keuangan daripada badan politik yang lebih besar, dan (3) kelebihan produksi yang substansial. Atribut-atribut ini menjamin posisi kepemimpinan untuk Arab Saudi tanpa peduli apakah orang menyukai versi kepemimpinan model yang kuat atau yang lemah (Doran 1979).

Melalui kekuatan produksinya, Arab Saudi mendapatkan keuntungan pendapatan yang besar terhadap sisi domestiknya. Arab Saudi mungkin adalah contoh petrostate paling murni di dunia. Lebih dari 60\% dari anggaran nasionalnya dan $75 \%$ dari pendapatan ekspor serta 40\% dari PDB 2016 dipasok oleh ekspor minyak (Sohail 2005). Sementara itu, di dalam struktur OPEC dominasi Arab yang nyatanya berdampak terhadap penetapan harga serta penyeimbangan harga dapat diukur melalui dua hal. Pertama, peran Arab Saudi sebagai swing supplier / swing producer dalam OPEC. Dalam hal ini Arab Saudi telah membentuk dirinya sebagai swing supplier minyak dunia, yang bertindak untuk memotong produksi ketika pasar berlebih dan meningkatkan output ketika pasokan terbatas (De Santis 2003). Tujuan yang dilakukan oleh Arab Saudi adalah untuk mempertahankan harga minyak dari OPEC itu sendiri. Kedua, strategi tit-for-tat milik Arab Saudi yang mampu menghukum anggota OPEC lainnya, apabila melakukan tindak kecurangan dalam produksi.

Salah satu dominasi serta pengaruh besar Arab Saudi terhadap OPEC terlihat dalam dinamika kesepakatan pemotongan produksi per anggota OPEC dari awal tahun 2014. Pemotongan produksi terjadi dikarenakan adanya pelemahan terhadap harga minyak dunia. Dalam menanggapi hal tersebut, OPEC melakukan serangkaian pemotongan produksi guna menstabilkan kuota produksi serta harga jual minyak bumi. Kesepakatan terhadap pemotongan produksi minyak bumi dipicu setelah adanya penurunan harga minyak bumi yang terjadi secara drastis. Antara Januari 2011 dan Juni 2014, harga minyak Brent relatif stabil di sekitar US \$ 110 per barel. Memasuki fase pertengahan tahun 2014, harga minyak bumi mulai mengalami penurunan yang signifikan. Bahkan harga 
minyak sempat mencapai titik terendah $\$ 27$ per barel pada awal 2016. Sebagai tanggapan, negara-negara anggota OPEC melakukan pertemuan pada November 2016 dengan beberapa negara penghasil minyak non-OPEC dalam pertemuan OPEC+ untuk melakukan unjuk kekuatan dengan menyetujui pengurangan produksi (Bordoff 2018).

Keseriusan OPEC dalam mengantisipasi harga minyak bumi tertuang dalam forum sidang OPEC untuk beberapa kali, dimulai dari sidang OPEC ke-171 sampai sidang OPEC ke-176 pada tanggal 1 Juli 2019. Dari keseluruhan sidang tersebut, telah menghasilkan berupa kesepakatan pemotongan produksi minyak terhadap negara anggota OPEC dan non-anggota OPEC. Kesepakatan pemotongan produksi minyak mulai disepakati sejak sidang OPEC ke-171 pada tanggal 30 November 2016. Diketahui, bahwa Arab Saudi sebagai pemasok minyak terbesar dunia, akan memangkas produksinya sebesar 500 ribu barel per hari pada bulan Desember untuk membantu menstabilkan pasar (Reed 2017). Sejalan dengan mengimplementasikan kebijakan serta selama proses persetujuan negara-negara anggota OPEC dan non-OPEC, Arab Saudi menjadi negara yang paling vokal dalam menyerukan pemotongan produksi. Menteri perminyakan Saudi, Khalid al-Falih, telah menghabiskan tahun lalu melobi kolega OPEC dan produsen lain seperti Rusia untuk menyetujui pengurangan produksi dan berpegang teguh pada mereka (Reed 2017).

Dominasi Arab Saudi dibayangi oleh Uni Emirat Arab yang tampak selalu mendukung penetapan kebijakan organisasi. Berdasar kata lain, dukungan ini kemudian menjadi justifikasi dari implementasi kebijakan-kebijakan yang diusulkan. Hal ini menunjukkan bahwa hubungan power terkait distribusi kepentingan hanya menitikberatkan pada negara-negara dengan kuota produksi yang besar dalam OPEC. Namun, keseimbangan itu tidak merata karena adanya perselisihan dengan negara anggota produsen besar yang lain. Seperti misalnya pada Pertemuan Doha yang berjalan tidak kondusif setelah Wakil Pangeran Mahkota Mohammed bin Salma tiba-tiba memblokir kesepakatan untuk membekukan produksi minyak karena Iran tidak ikut dalam perjanjian formal (Munro 2016). Diketahui bahwa, dari tahun 2014-2016, keberadaan serta perilaku Iran menjadi salah satu faktor kunci mengapa Arab Saudi cenderung tidak ingin menyepakati pemotongan produksi. Hal ini disebabkan karena sebelumnya Arab Saudi sempat terlibat perseteruan dengan Iran akibat adanya perilaku Iran yang secara mengejutkan meningkatkan produksi minyak secara sepihak guna mencari keuntungan ekonomi. 
Perselisihan ini memberikan dampak juga terhadap posisi Qatar dalam Organisasi. Diketahui Qatar menjalin hubungan diplomatik yang semakin meningkat dengan Iran. Melihat hal ini, Arab Saudi, UEA, Bahrain dan Mesir secara sepihak untuk memutus hubungan diplomatik dengan Qatar pada 5 Juni 2017. Negara tersebut melakukan pengusiran terhadap warga negara Qatar, membekukan hubungan diplomatik, menutup satu-satunya perbatasan darat Qatar, menutup ruang angkasa mereka, dan menghentikan relasi dagang (Pinnell 2018). Arab Saudi cenderung akan menggunakan kekuatan produksinya untuk menekan kedua negara di dalam OPEC. Bahkan khususnya Qatar, apabila ia terus berlanjut melakukan peningkatan kerja sama dengan Iran. Sejak awal perselisihan Aliansi Saudi dengan Qatar, menteri perminyakan dan delegasinya hampir menjadi orang buangan di pertemuan OPEC. Pertemuan terakhir di Wina menjelaskan bahwa mayoritas menteri OPEC tidak akan secara terbuka berbicara dengan rekan-rekan mereka dari Qatar dan Iran (Widdershoven 2018). Selain itu, dominasi yang dilakukan oleh Arab Saudi nyatanya mampu mempengaruhi pengadopsian kebijakan luar negeri negara anggota OPEC lainnya. Di sisi lain, hubungan power antara Irak dan Kuwait juga menjadi sorotan karena perseteruan kedua negara pada akhirnya menambah kondisi instabilitas dalam organisasi.

Kondisi ini menyebabkan adanya ketidakseimbangan dari eksekusi pengambilan kebijakan dalam organisasi internasional. Kenyataan yang muncul adalah OPEC tidak mampu memberikan sikap netral terhadap negara-negara yang tidak memiliki kuota produksi yang besar, sehingga proses diplomasi beberapa kali terhambat karena adanya relasi power yang tidak seimbang dan mempengaruhi distribusi kepentingan oleh masing-masing negara anggota. Hal ini terlihat dari tanggapan Qatar melalui pernyataan Menteri Energi dan Industrinya, Saad Al-Kaabi, "We are not saying we are going to get out of the oil business, but it is controlled by an organization managed by a country" (The New York Times 2018). Selain AlKaabi, Perdana Menteri Qatar, Shiekh Hamad Bin Jassim juga menyatakan bahwa, "meninggalkan OPEC adalah keputusan yang masuk akal, karena telah menjadi organisasi yang tidak berguna yang tidak menambah apa pun pada kami, dan hanya digunakan untuk tujuan yang membahayakan kepentingan nasional kami." (Gross dan Ghafar 2018).

\section{Dinamika Hubungan Qatar dengan Negara Anggota OPEC}

Berdasarkan gambaran ketidakseimbangan relasi power di sub-bab sebelumnya, maka tinjauan terhadap hubungan sosial antara Qatar 
dengan negara-negara dominan tersebut juga perlu dilakukan. Hal ini penting karena tren yang terjadi adalah relasi power dan sosial antar negara anggota dalam organisasi nyatanya memiliki hubungan sebab-akibat yang resiprokal. Negara-negara anggota yang selalu terpecah karena konflik politik dan regional di Timur Tengah, yang telah mempengaruhi eksistensi OPEC (Ahmad 2016). Oleh karenanya, sub-bab ini fokus pada hubungan sosial antara Qatar dengan Arab Saudi, Uni Emirat Arab (UEA) dan Iran.

Menurut rekam sejarah, hubungan Qatar dengan Arab Saudi sudah menunjukkan dinamika yang kurang baik. Apabila dilihat dari tahun-tahun sebelumnya, perseteruan antara Saudi dengan Qatar terjadi sejak periode pertengahan abad ke-20. Pada periode tersebut, perseteruan terpusat pada sengketa perbatasan dan sempat melibatkan beberapa negara lain di wilayah Teluk. Lalu di awal tahun 2014, Arab Saudi, UEA, dan Bahrain sempat melakukan pembekuan hubungan diplomatik, disebabkan perseteruan akibat perbedaan dukungan politik dalam fenomena Arab Spring. Kemudian pada tahun 2016 lalu setelah munculnya beberapa insiden yang mengisyaratkan adanya dukungan Qatar kepada beberapa kelompok yang dipandang oleh Arab Saudi Saudi, UEA, dan Bahrain serta Mesir sebagai kelompok teror, termasuk perubahan afiliasi Hamas dari Riyadh ke Doha, hubungan diplomatik antara Qatar dengan negara-negara tersebut kembali memburuk.

Perseteruan Qatar dan Arab Saudi kembali terjadi pada tahun 2017. Memanasnya hubungan bilateral antara Arab Saudi dan Qatar secara fundamental disebabkan oleh munculnya rasa kecemburuan serta kecurigaan Arab Saudi terhadap peningkatan kerja sama antara Qatar dan Iran. Selain itu, krisis diplomatik antara Qatar dan Arab Saudi juga didorong oleh sebab-sebab lain, seperti pelanggaran terhadap Riyadh Agreement. Arab Saudi menuduh Qatar melanggar Riyadh Agreement dengan poin bahwasanya Qatar masih memberikan dukungan kepada kelompok-kelompok Islam radikal seperti Ikhwanul Muslimin, Hamas, Al-Qaeda, ISIS, dan afiliasi teroris radikal di Libya (Pinnell 2018). Berdasarkan tuduhantuduhan tersebut, maka Arab Saudi dengan tegas mengeluarkan kebijakan luar negeri yang bersifat reaktif terhadap Qatar, yakni pemutusan hubungan diplomatik serta boikot ekonomi pada tahun 2017. Selain itu, diketahui bahwa Arab Saudi juga menutup perbatasannya dengan Qatar di sektor udara dan laut. Posisi Qatar di antara negara-negara tetangganya selalu dalam kondisi waspada (Cahyani 2019). 
Sama halnya dengan Arab Saudi, Uni Emirat Arab juga sempat mengalami perseteruan dengan Qatar sebelum tahun 2017. Tepatnya pada Peristiwa Arab Spring, keduanya terlibat perselisihan karena Qatar dituduh mendukung Ikhwanul Muslimin (Cahyani 2019). Hal ini berdampak pada pemutusan hubungan diplomatik dan boikot pada Juni 2017. Secara langsung, perseteruan Uni Emirat Arab ini juga mengikuti sikap Arab Saudi terhadap Qatar yang melakukan penutupan akses terhadap wilayah darat, laut dan udara. Perselisihan ini masih terlihat jelas bahkan setelah Qatar menyatakan diri keluar dari OPEC. Uni Emirat Arab justru menanggapi bahwa keluarnya Qatar dari OPEC tidak akan mempengaruhi jumlah produksi minyak dunia karena persentasenya yang tidak begitu signifikan. Sekalipun tidak secara langsung berkaitan dengan komoditas minyak, nyatanya penurunan hubungan antara Qatar-Arab Saudi dan Qatar-Uni Emirat Arab tidak dapat dipandang mudah. Perseteruan antara ketiga negara tersebut memang tidak melibatkan adanya konfrontasi militer. Namun, tidak dapat dipungkiri jika Arab Saudi dan Uni Emirat Arab memang memiliki posisi penting dalam OPEC. Ditambah lagi keduanya menunjukkan hubungan yang saling mendukung, sehingga perselisihan bilateral suatu negara dengan keduanya dapat memiliki dampak pada relasi di dalam organisasi.

Apabila konteks hubungan sosial antara Qatar dengan negara anggota OPEC yang dominasinya didasarkan pada fenomena dukungan terhadap kelompok teror. Maka, konteks hubungan sosial kedua yang dapat mempengaruhi keputusan Qatar untuk keluar dari OPEC. Hal ini dapat terjadi demikian karena didasarkan pada peningkatan hubungan Qatar dengan Iran. Peningkatan tensi antara Arab Saudi dan Uni Emirat Arab dengan Qatar, juga disebabkan karena adanya peningkatan intensitas kerja sama bilateral antara Qatar dengan negara rival Arab Saudi, yakni Iran. Sejak tahun 2010, Qatar dan Iran memang saling memperdalam hubungan bilateral mereka. Beberapa kerja sama yang dilakukan oleh Qatar dan Iran adalah memerangi penyelundupan dan obat-obatan terlarang, pemalsuan, dan pencucian uang. Kemudian pada tahun 2014, pada upaya untuk memperluas hubungan perdagangan dan ekonomi, bersamaan dengan penandatanganan beberapa protokol keamanan, kedua negara mengumumkan pembentukan tiga zona perdagangan bebas-gabungan, satu terletak di kota pelabuhan Bushehr di Iran dan dua lainnya di Qatar, di Doha dan pelabuhan AlRuwais. Pada tahun 2015, perdagangan Qatar-Iran diperkirakan sekitar \$ 500 juta (Qatar-America Institute 2019).

Secara spesifik di bidang energi, Qatar dan Iran saling bekerja sama dalam mengelola sumber daya gas alam di wilayah Teluk 
Persia. Qatar dan Iran sama-sama memiliki ladang Gas-Kondensat South Pars atau North Dome. Qatar dan Iran bersama-sama saling mengontrol ladang gas alam tersebut. Qatar yang memiliki $13 \%$ cadangan gas di dunia dan memproduksi 650 juta meter kubik gas per hari dari bagian ladangnya, sedangkan Iran dapat memproduksi hingga 5.750 juta meter kubik gas dari ladangnya tersebut (QatarAmerica Institute 2019). Kepemilikan sumber daya tersebut mampu memiliki pengaruh geostrategis yang signifikan bagi kedua negara. Secara bilateral, jumlah cadangan gas alam tersebut memberikan prospek yang baik terhadap pendapatan serta peningkatan ekonomi domestik serta mampu menimbulkan hubungan bilateral yang akan semakin kuat antara Qatar dengan Iran.

Sekalipun dianggap menguntungkan bagi kedua negara, tata kelola kepemilikan sumber daya alam antara Iran dan Qatar mampu menjadi pemicu terhadap gejolak tendensi geopolitik di wilayah Timur Tengah. Hal ini dikarenakan kerja sama pengelolaan sumber daya yang sangat besar ini mampu menjadi sumber kekuatan politik baru di kawasan. Dengan demikian, akan muncul perasaan tidak aman dan terancam dari negara-negara yang sudah mendominasi kawasan, khususnya Arab Saudi. Arab Saudi yang didukung Uni Emirat Arab lantas menyerukan Anti-Iran di wilayah Timur Tengah. Terdapat 13 tuntutan yang diminta oleh koalisi Arab Saudi terhadap Qatar, yang salah satunya menginginkan Qatar untuk melakukan pemutusan hubungan diplomatik dengan Iran (Aljazeera 2017). Maka demikian, Iran menjadi salah satu alasan Qatar mendapatkan sanksi blokade oleh Arab Saudi dan Uni Emirat Arab.

Sementara itu, setelah dilakukannya pemutusan hubungan diplomatik serta boikot oleh Arab Saudi, Uni Emirat Arab, Bahrain, dan Mesir, akhirnya Qatar dengan tegas menolak segala tuduhan yang disebutkan terkait dengan konsolidasi bersama Iran serta dukungan terharap kelompok teori. Qatar juga menganggap tuduhan yang dilayangkan oleh keempat negara tersebut merupakan tuduhan yang cenderung berusaha menyudutkan Qatar. Pemerintah Qatar menganggap bahwa keputusan itu adalah pelanggaran kedaulatannya. Qatar telah berulang kali menolak tuduhan memiliki hubungan dengan kelompok-kelompok radikal yang dapat mengancam keamanan dan stabilitas kawasan Timur Tengah dan menganggap tuduhan tersebut sebagai tuduhan yang tidak berdasar (Savitri dan Mulyana, 2018).

Hubungan sosial yang pada akhirnya berpengaruh pada dinamika dalam organisasi internasional ini menggambarkan adanya ketidakharmonisan antara Qatar dengan negara-negara dominan 
di kawasan Timur Tengah dan OPEC. Dampak paling jelas adalah bahwa para menteri tidak bisa bertemu, menteri-menteri Saudi dan UEA tidak bisa bertemu di tempat umum dengan menteri-menteri Qatar (Gamal dan Zhdannikov, 2017). Seiring dengan semakin mendalam pertikaian antara Arab Saudi dan Qatar, salah satu sumber menyebutkan bahwa dulu ada WhatsApp grup untuk semua menteri dan delegasi dari negara-negara Teluk. Biasanya chatroom itu sibuk sekali, sekarang senyap," kata sumber di OPEC. Bahkan hingga tidak ada kontak resmi mengenai kebijakan minyak antara negara-negara Arab Teluk yang tergabung dalam Dewan Kerja Sama Teluk (GCC) (Gamal dan Zhdannikov, 2017).

Dalam hal ini, OPEC sekali lagi tidak mampu menjadi aktor independen yang bisa memisahkan antara kepentingan politik yang sifatnya bilateral dengan kepentingan bersama terkait dengan stabilitas pasar energi global di sektor minyak bumi. Dalam kata lain, hal ini dapat menghambat berjalannya lembaga internasional sebagai instrumen penting atau bahkan aktor yang berdaulat dalam politik dunia sendiri untuk kerja sama antar negara dalam sistem internasional (Finnemore and Barnett, 2004). Akibatnya, dapat terjadi ketidakharmonisan dalam hubungan sosial antara Qatar dengan negara anggota OPEC lain yang memiliki dominasi peran menjadi salah satu faktor bagi Qatar untuk mengambil kebijakan luar negeri dalam bentuk mengakhiri keanggotaannya di organisasi internasional.

\section{Kesimpulan}

Terhitung Qatar telah menjadi anggota aktif OPEC selama 57 tahun. Qatar bergabung ke dalam anggota aktif OPEC sejak dari tahun 1961, hingga pada tahun 2019 awal ini Qatar memutuskan untuk keluar dari keanggotaan OPEC. Melalui konsep kebijakan luar negeri dengan determinan faktor eksternal, dapat disimpulkan bahwa terdapat dua hal yang melatarbelakangi keluarnya Qatar dari OPEC. Pertama yakni pengaruh hubungan power yang tidak seimbang dalam mendistribusikan kepentingan dan pengaruh hubungan sosial antar negara anggota. Oleh karenanya, dinamika yang berlangsung di dalam OPEC menjadi salah satu penyebab diambilnya kebijakan luar negeri Qatar untuk mengakhiri masa keanggotaan di organisasi tersebut. Hubungan power yang tidak seimbang dalam mendistribusikan kepentingan disebabkan karena adanya dominasi dari negara-negara OPEC dengan kuota produksi yang besar dalam proses pengambilan kebijakan organisasi. Dalam hal ini sebenarnya permasalahan yang muncul adalah adanya dominasi yang terlihat jelas, sehingga memberikan ruang yang sempit bagi negara anggota 
yang lain. Kedua, hubungan sosial yang tidak harmonis secara politik antara Qatar dengan negara-negara dominan ini pada akhirnya berdampak pada relasi yang dibangun dalam organisasi. Tuduhan terhadap Qatar yang dianggap mendukung kelompok teror di kawasan Timur Tengah dan meningkatnya intensitas kerja sama dengan Iran, menjadikan adanya sentimen dari negara dominan di OPEC dan juga di kawasan. Dalam hal ini pula, OPEC pada akhirnya memiliki sikap yang bias terhadap kondisi internal antara negara anggotanya. OPEC tidak bisa menjadi aktor independen yang fokus terhadap kepentingan bersama yang secara khusus berkaitan dengan pasar energi global, yakni minyak bumi. 


\section{Daftar Pustaka}

\section{Buku}

Ahmad, P., 2016. Political Tension in OPEC. PRO PUBLICO BONO - Magyar Közigazgatás, 2016/2, 118-137.

Bouoiyour, J., \& Selmi, R., 2019. The Qatar-Gulf Crisis and Risk Management in Oil and Gas Markets. No. 02101633.

Finnemore, M. and M.N. Barnett, 2004. Rules for the World: International Organizations in Global Politics. Ithaca, NY: Cornell University Press.

Neack, Laura, 2008. The New Foreign Policy: Power Seeking in a Globalized Era. Plymouth: Rowman \& Littlefield Publishers.

\section{Jurnal}

Bojang, AS, 2018. "The Study of Foreign Policy in International Relations", Journal of Political Sciences \& Public Affairs, 6(4). Doi: 10.4172/2332-0761.1000337.

Cahyani, S. B, 2019. "Faktor-Faktor Manuver Politik Qatar dalam Penguatan Aliansi dengan Iran Pasca Kasus Krisis Diplomatik Qatar Tahun 2017". Journal of International Relations, 5(3):517-527.

De Santis RA, 2003. "Crude oil price fluctuations and Saudi Arabia's behavior”. Energy Economics, 2(5): 155-173.

Doran, C. F, 1979. "Three models of OPEC leadership and policy in the aftermath of Iran". Journal of Policy Modeling, 1(3):413424. doi:10.1016/0161-8938(79)90006-1.

Shi, M, 2017. "State withdrawal from international institutions: changing social relations within divergent institutions". International Politics, 55(2):221-241. DOI: /10.1057/ s41311- 0170121-1.

Singer, J. David, 1961. "The Level of Analysis Problem in International Relations", The International System: Theoretical Essays, 14(1). DOI: 10.2307/2009557. 
Sohail, M. Sadiq, 2005. "Sustaining Trade with Saudi Arabia: An Analysis of Exporting as Alternative", World Review of Entrepreneurship Management and Sustainable Development, 1(1):77-90. DOI: 10.1504/WREMSD.2005.007754.

\section{Jurnal Online}

Savitri, A. A. \& Mulyana, B., 2018. Hubungan Arab Saudi dan Qatar Pasca Pemutusan Hubungan Diplomatik Tahun 2017. [online]. https://elib.unikom.ac.id/ files/disk1/ 799/jbptunikompp-gdl-astriaudin-39936-11-unikom_ a-l.pdf [Diakses 27 Januari 2020].

\section{Media Massa Online}

Al Jazeera, 2017. Arab States Issue 13 Demands to End Qatar-Gulf Crisis. [online]. http://www.aljazeera.com/news/2017/o6/ arab-states-issue-list-demands-qatar-crisis1706230221 33024.html. [Diakses 29 Januari 2020].

BBC, 2018. Oil Prices Rise on Planned OPEC Cuts. [online]. https://www. bbc.com/ news/ business-46488369. [Diakses 1 Februari 2020].

Bordoff, J., 2018. This Isn't Your Father's OPEC Anymore. [online]. https://foreignpolicy.com/2018/06/26/this-isntyour-fathers-opec-anymore/ [Diakses 1 Februari 2020].

Gamal, R. E, 2017. OPEC chatroom dead as Qatar crisis hurts Gulf oil cooperation. [online]. https://www. reuters.com/ article/us-opec-gulf-qatar/opec-chatroom-dead-as-qatar-crisis- hurts-gulf-oil-cooperation-idUSKBN1DNoTU. [Diakses 3 Februari 2020].

Gross, S. \& Ghafar, A.A., 2018. Qatar Breaks Up with OPEC: It's not you, it's me. [online]. https://www.brookings.edu/blog/ order-from-chaos/2018/12/05/qatar-breaks-up-with-opecits-not-you-its-me/ [Diakses 1 Februari 2020].

IEA, 2015. Qatar. [online]. https://www.eia.gov/beta/international/ analysis includes/countri eslong/Qatar/qatar.pdf [Diakses 3 Februari 2020]. 
Munro, D., 2016. Sudden Saudi Policy Shift Doha Injects a New Level of Volatility into Oil Market. [online]. https://agsiw.org/ sudden-saudi-policy-shift-in-doha-injects-a-new-level-ofvolatility-into-oil-markets/ [Diakses 5 Februari 2020].

Pinnell, O., 2018. Qatar dan Arab Saudi terlibat pertempuran di dunia maya. [online]. https://www.bbc.com/indonesia/ dunia-44345683 [Diakses 5 Februari 2020].

Qatar-America Institute, 2019. Demystifying Iran Trade. [online]. https:// qataramerica. org/ projects/demystifying-iran-trade/ [Diakses 7 Februari 2020].

Reed, S., 2017. Saudi Arabia Drive OPEC to Extend Oil Production Cuts. [online]. https://www.nytimes.com/2017/11/30/ business/energy-environment/opec-saudi-arabia-oilmeeting.html [Diakses 5 Februari 2020]

Sabga, P., 2018. Qatar quits OPEC as Saudis walk tightrope on oil prices. [online]. https://www.aljazeera.com/ news/2018/12/qatar-quits-opec-saudis-walk-tightropeoilprices-181203222739862.html [Diakses 7 Februari 2020].

The New York Times, 2018. Qatar Says that It Would Leave OPEC and Focus on Natural Gas. [online]. https://www.nytimes. com/2018/12/ 03/ world/ middleeast/ qatar- withdraw- opec.html [Diakses 9 Februari 2020].

US-Qatar Business Council, n.d. Economics in Qatar. [online]. https://www.usqbc.org/economics-in-qatar [Diakses 9 Februari 2020].

Wang, T, 2019. Natural Gas production Qatar 1998 - 2018. [online]. https://www.statista.com/statistics/265336/natural-gasproduction-in-qatar/ [Diakses 3 Februari 2020].

Widdershoven, C., 2018. Qatar Irrational Decision To Leave OPEC. [online]. https://oilprice.com/Energy/Energy-General/ Qatars-Irrational-Decision-To-Leave-OPEC.html [Diakses 7 Februari 2020]. 